\title{
ESTIMATION OF HEMOGLOBIN A C USING THE COMPLETE BLOOD COUNT MEASURES IN THE DIAGNOSIS OF DIABETES
}

\author{
VINUPRITHA P1 ${ }^{1}$, HARIHARAN M ${ }^{1 *}$, KATHIRVELU D ${ }^{1}$, CHINNADURAI S \\ ${ }^{1}$ Department of Biomedical Engineering, SRM University, Kattankulathur, Chennai - 603 203, Tamil Nadu, India. ${ }^{2}$ Manager, Central Clinical \\ Laboratory, SRM Medical College Hospital and Research Centre, SRM University, Kattankulathur, Chennai - 603 203, Tamil Nadu, India \\ Email: wavelet.hari@gmail.com \\ Received: 26 April 2017, Revised and Accepted: 27 May 2017
}

ABSTRACT

Objective: Diabetes is a metabolic disorder occurring either due to the inadequate secretion of insulin or ineffective utilization of insulin by the body. The study was aimed to identify the variations of the complete blood count (CBC) parameters among the diabetic and normal individuals and to derive an empirical formula to estimate hemoglobin $\mathrm{A}_{1} \mathrm{c}\left(\mathrm{HbA}_{1} \mathrm{c}\right)$ of an individual using $\mathrm{CBC}$ parameters.

Methods: A total of 83 subjects (mean age: 52.8 \pm 9.0 years) involved in the study, among which 39 (mean age: $49.1 \pm 8.8$ years) were normal and 44 (mean age: $56 \pm 7.8$ years) were diabetic. The blood was drawn from the participants and was subjected to CBC analysis using automated hematology analyzer. The stepwise linear regression model was used to determine the empirical formula to estimate $\mathrm{HbA}_{1} \mathrm{c}$ using the $\mathrm{CBC}_{\mathrm{C}} \mathrm{parameters.} \mathrm{The}$ Student's t-test was performed to identify the group differences.

Results: A negative correlation was observed for $\mathrm{Hb}\left(\mathrm{r}=-0.35^{* *}, \mathrm{p}<0.001\right)$ and packed cell volume $(\mathrm{PCV})\left(\mathrm{r}=-0.23^{* *}, \mathrm{p}<0.05\right)$ against $\mathrm{HbA}$ c. The CBC parameters $\mathrm{Hb}$, erythrocyte sedimentation rate, $\mathrm{PCV}$, red blood cells count, mean corpuscular volume, and mean corpuscular Hb exhibited a statistically significant difference at the level $(\mathrm{p}<0.05)$ between the normal and diabetic groups. The empirically derived formula yielded sensitivity, specificity, positive predictive value, negative predictive value, and accuracy measures of $91 \%, 49 \%, 67 \%$, 83\%, and $71 \%$, respectively, in diagnosing diabetes based on the estimated $\mathrm{HbA}_{1} \mathrm{c}$.

Conclusion: The empirical formula derived to estimate $\mathrm{HbA}_{1} \mathrm{c}$ could be useful in the prediction of diabetes with an appreciable accuracy.

Keywords: Diabetes, Complete blood count, Estimated hemoglobin A1c, Hematology analyzer, Stepwise multivariate linear regression.

(C) 2017 The Authors. Published by Innovare Academic Sciences Pvt Ltd. This is an open access article under the CC BY license (http://creativecommons. org/licenses/by/4. 0/) DOI: http://dx.doi.org/10.22159/ajpcr.2017.v10i9.19407

\section{INTRODUCTION}

Diabetes is a chronic health disorder that occurs if the pancreas fails to secrete sufficient insulin or the secreted insulin cannot be effectively used by the body. Insulin is a hormone which is responsible for regulating the levels of glucose in the blood. The glucose molecules are responsible for providing adequate energy for cell survival; else if the glucose molecules are not assimilated by the cell, their concentration rises to dangerous levels in the blood. Long-term complications of diabetes can be controlled by continuing medical care and patient self-management education [1]. Morbidity and mortality are the main concern for those with diabetes, and the risk of complications increases with the degree and the duration of the disease. The elevated blood glucose levels can result in serious, life-threatening complications to the human body such as heart failure, stroke, nervous disorder, renal failure, eye blindness, impotency, and bodily infections that can even result in partial or complete amputations. The survey taken by the Center for Disease and Prevention in US says that diabetes is the sixth-leading cause of death [2]. Diabetes is categorized into three main types, namely, Type I, Type II, and gestational diabetes. Type I is those who need everlasting insulin injections for survival and develops either in their childhood or at teenage years. Type II is the one which is widespread among the majority of population and occurs due to obesity, physical inactivity, and inappropriate and inadequate diet. Gestational diabetes happens only during pregnancy and is momentary $[3,4]$. Worldwide statistics reveal that India and China are with more number of diabetic patients than any other nations in the world $[5,6]$. It has been estimated that about 62 million Indians are diabetic, which corresponds to about 7.1\% of the adult population. The mean age of the onset of diabetes among the Indian population was 42.5 years, and the disease resulted in about 1 million deaths every year [6,7]. Studies by the Indian Heart Association revealed that about 109 million individuals would be diabetic by 2035 . The high prevalence of the disease among the India's increasing middleclass population is mainly due to genetic vulnerability and adoption of a high-calorie, low-physical activity lifestyle [8-10].

Blood is a bodily fluid that provides necessary nutrients and oxygen to the cells and excretes the metabolic wastes away from them. Blood is composed of the major constituents, namely, erythrocytes or red blood cells (RBCs), leukocytes or white blood cells (WBCs), and thrombocytes (platelets). The main role of RBC is for transporting oxygen from the lungs to tissues and carbon dioxide from tissues to the lungs. WBC is responsible for providing the necessary immune system to the human body, and platelets are accountable for coagulation of blood [11]. A complete blood count ( $\mathrm{CBC}$ ) is a blood test performed to assess the overall health of an individual and to diagnose various disorders that affect the composition of blood. A CBC test gives the measure of RBC count, packed cell volume (PCV), RBC indices, mean corpuscular volume (MCV), mean corpuscular hemoglobin $(\mathrm{MCH}), \mathrm{MCH}$ concentration (MCHC), WBC types, and platelet count. Abnormal levels in the cell count and composition in a $\mathrm{CBC}$ test may indicate an underlying medical condition that recommends for further assessment [12]. Hemoglobin $(\mathrm{Hb})$ is a protein that contains an iron molecule that makes the blood to appear red in color. It is responsible for the transport of oxygen from the lungs to the other parts of the body. In the case of diabetes, excess glucose in the blood attaches to $\mathrm{Hb}$ molecule and elevates the level of $\mathrm{HbA}_{1} \mathrm{c}$ [4]. The measure of $\mathrm{HbA}_{1} \mathrm{c}$ is clinically regarded as an index of diabetes diagnosis [13]. Elevated levels of $\mathrm{HbA}_{1} \mathrm{c}$ can impair endothelium-mediated vasoactive responses that 
can result in cardiovascular diseases among diabetic individuals [14]. $\mathrm{RBC}$ is nucleated cells composed of $\mathrm{Hb}$, which is biconcave disc shaped with a diameter ranging from 6 to $9 \mu \mathrm{m}$ and thickness in the range of 1.5-2.5 $\mu \mathrm{m}$. The RBC appears as distributed cells with a dense and darker outer ring with a paler center, which occupies one-third of the diameter. The varying concentrations of $\mathrm{Hb}$ in the blood result in the variations in shape, texture, size, and color [15].

Earlier studies on RBC have revealed that the RBC undergoes morphological variations on the incidence of various diseases such as diabetes mellitus, malaria, sickle cell anemia, and hypercholesterolemia [16-18]. There are numerous intracellular mechanisms that are responsible for modifications in RBC membrane lipids and proteins which cause variations in the shape of RBC and its deformability [19-23]. Earlier studies have shown that biochemical and hematological measures exhibited significant differences in the normal with the diabetic subjects [24]. The changes in the blood composition are most common for any disease, and the CBC measures could be used to assess the extent of the disease and the treatment efficacy [25].

Hence, the aim of the study was to identify the variations of the CBC parameters among diabetes and normal individuals and to derive an empirical formula to estimate $\mathrm{HbA}_{1} \mathrm{c}$ of individual using $\mathrm{CBC}$ parameters.

\section{METHODS}

\section{Study subjects}

The study was carried out at SRM Hospital and Research Centre in Kattankulathur, SRM University, with the consent of the Institutional Ethical Committee. The participants for the study were those who visited the hospital for their routine diabetes checkup during October 2015 to November 2015. An informed written voluntary consent was obtained from all participants who willingly took part in the study. A total of 83 subjects (mean age: $52.8 \pm 9.0$ years) involved in the study, among which 42 (mean age: 52.1 \pm 9.5 years) were men and 41 (mean age: $53.5 \pm 8.5$ years) were women.

The exclusion criteria included subjects with known cardiovascular disorders, thyroid, arthritis, and unknown ethnicity based on information furnished by the subjects in the questionnaire.

\section{Biochemical test}

The subjects considered for the study were subjected to a complete history taking and clinical examination. Blood samples $(5 \mathrm{ml})$ were collected from every subject using white pore needles and were recommended for the following laboratory tests: Fasting blood glucose (FBG), post-prandial blood sugar (PPBS), $\mathrm{HbA}_{1} \mathrm{c}$, and estimated average glucose (eAG).The FBG was obtained using the glucose oxidaseperoxidase (GOD-POD) technique, and the reference values were set at $70-110 \mathrm{mg} / \mathrm{dl}$. The PPBS was also obtained using the GOD-POD technique, and the reference values were set at $80-140 \mathrm{mg} / \mathrm{dl}$. The $\mathrm{HbA}_{1} \mathrm{c}$ measures were obtained using the high-performance liquid chromatography (HPLC) method, and the reference values were set at 4.5-6\%. The eAG was estimated from $\mathrm{HbA}_{1} \mathrm{c}$, and the reference values were set at $<126 \mathrm{mg} / \mathrm{dl}$ [26-29].

\section{CBC parameters}

The $\mathrm{CBC}$ analysis was performed using an automated analyzer to estimate the $\mathrm{RBC}$ parameters, namely, $\mathrm{Hb}(\mathrm{g} / \mathrm{dl})$, erythrocyte sedimentation rate (ESR) $(\mathrm{mm} / \mathrm{hr}), \mathrm{PCV}(\%), \mathrm{RBC}$ count $\left(10^{12}\right.$ cells $\left./ \mathrm{L}\right)$, MCV (FL), MCH (pg/cell), MCHC (g/dl), and platelet count $\left(10^{9} / \mathrm{L}\right)$. The various $\mathrm{CBC}$ measures are defined as follows:

- Hb: It is the measure of oxygen-carrying protein in the blood

- ESR: It defines the rate of RBC sedimentation in $1 \mathrm{hr}$

- PCV: It is the percentage of RBC in the circulating blood

- Platelet count: It is the measure of platelets in a defined volume of blood

- RBC count: It is the measure of the actual number of RBC per volume of blood

- MCV: It is the mean volume of the RBC in the given sample of blood
- $\mathrm{MCH}$ : It is mean weight of $\mathrm{Hb}$ per $\mathrm{RBC}$ in the given sample of blood

- MCHC: It is the measure of the average concentration of $\mathrm{Hb}$ in the given volume of packed $\mathrm{RBC}$

\section{Statistical analyses}

The data collected from the study were analyzed using the SPSS software package version 17.0 (SPSS Inc., Chicago, IL, USA). The ANOVA test was performed for comparison and to calculate the average values for all parameters considered in the study. The comparison between the normal and the diabetic groups for all the parameters included in the study was carried out by the Student's t-test. The influence of the $\mathrm{CBC}$ measures on the levels of $\mathrm{HbA}_{1} \mathrm{c}$ was established by carrying out stepwise multivariate linear regression.

\section{Performance assessment}

It is essential to assess the performance of a diagnostic test based on sensitivity, specificity, and accuracy measures. Hence, a confusion matrix was formed based on the following considerations.

- True positive (TP): The person who has diabetes is also predicted as diabetic

- False positive (FP): The subject who is healthy but is predicted as diabetic

- True negative (TN): The subject who is healthy is also predicted as healthy

- False negative (FN): The subject who is diabetic but is predicted as healthy

- Sensitivity: It corresponds to accuracy measure for the true prediction of diabetes and is defined by the following equation:

$$
\text { Sensitivity }=\frac{\mathrm{TP}}{\mathrm{TP}+\mathrm{FN}} \%
$$

- Specificity: It corresponds to accuracy measure of diagnosis of healthy subjects and is defined by the following equation:

$$
\text { Specificity }=\frac{\mathrm{TN}}{\mathrm{FP}+\mathrm{TN}} \%
$$

- Overall accuracy (Efficiency): It is a measure of true findings of the diagnostic test and is defined by the following equation:

$$
\text { Accuracy }=\frac{\mathrm{TP}+\mathrm{FN}}{\mathrm{TP}+\mathrm{FP}+\mathrm{FN}+\mathrm{TN}} \%
$$

\section{RESULTS}

The blood samples collected from the study population were subjected to biochemical assays to quantify PPBS, FBS, $\mathrm{HbA}_{1}$, eAG, and the $\mathrm{CBC}$ parameters. The stepwise linear multivariate regression was used to empirically derive the formula to estimate $\mathrm{HbA}_{1} \mathrm{c}$ using the $\mathrm{CBC}$ measures. Among the various $\mathrm{CBC}$ measures, it was found that only $\mathrm{Hb}$ plays a predominant role in the estimation of $\mathrm{HbA}_{1} \mathrm{c}$ and is shown in the following equation:

Estimated $\mathrm{HbA}_{1} \mathrm{c}=(-0.508 \times \mathrm{Hb})+13.906$

The Pearson correlation test results of the chronological, CBC parameters, and the derived $\mathrm{HbA}_{1} \mathrm{c}$ against the biochemically measured $\mathrm{HbA}_{1} \mathrm{c}$ are presented in Table 1 . It was observed that there exists a negative correlation for $\mathrm{Hb}\left(\mathrm{r}=-0.35^{* *}, \mathrm{p}<0.001\right)$ and PCV $\left(\mathrm{r}=-0.23^{* *}\right.$, $\mathrm{p}<0.05$ ) against $\mathrm{HbA}_{1} \mathrm{c}$, which clearly indicates that elevated blood glucose levels results in reduced $\mathrm{Hb}$.

The Student's t-test was performed to identify the differences that existed between the normal and diabetic groups based on the $\mathrm{HbA}_{1} \mathrm{c}$ determined using the biochemical method and the derived empirical formula are presented in Tables 2 and 3, respectively.

Table 2 reveals that there exists a statistically significant difference at the level $(\mathrm{p}<0.05)$ for FBS, PPBS, $\mathrm{HbA}_{1} \mathrm{c}$, eAG, HB, ESR, PCV, RBC count, $\mathrm{MCV}$, and $\mathrm{MCH}$ between the normal and diabetic groups among the entire population as well as for both the genders. Similar observations were also evident when such comparison was made between the 
Table 1: Pearson correlation coefficient (r) of chronological, CBC parameters, and estimated $\mathrm{HbA}_{1} \mathrm{c}$ against biochemically measured $\mathrm{HbA1} \mathrm{C}$ among the total studied population

\begin{tabular}{lll}
\hline Characteristics & $\begin{array}{l}\text { Total population } \\
\text { (Mean } \pm \text { SD) }\end{array}$ & HbA $_{\mathbf{1}} \mathbf{c}(\%)$ (r) \\
\hline Chronological & & \\
Age (years) & $52.8 \pm 9.0$ & 0.2 \\
Hb (g/dl) & $13.4 \pm 1.3$ & $-0.35^{* *}$ \\
ESR (mm/hr) & $17.1 \pm 11.0$ & $0.35^{* *}$ \\
PCV (\%) & $39.1 \pm 3.9$ & $-0.23^{*}$ \\
CBC parameters & & \\
Platelet count $\left(10^{9} / \mathrm{L}\right)$ & $236,397.6 \pm 73,891.8$ & -0.03 \\
RBC count $\left(10^{12}\right.$ cells/L) & $4.7 \pm 0.5$ & -0.18 \\
MCV (fl) & $83.3 \pm 3.8$ & -0.15 \\
MCH (pg/cell) & $28.5 \pm 3.8$ & -0.22 \\
MCHC (g/dl) & $34 \pm 1.6$ & 0.05 \\
Derived measure & & \\
Estimated HbA ${ }_{1} \mathrm{c}(\%)$ & $7.1 \pm 0.7$ & $0.36^{* *}$ \\
\hline
\end{tabular}

${ }^{* *}$ Correlation is significant at the 0.01 level (two-tailed), ${ }^{*}$ Correlation is significant at the 0.05 level (two-tailed). SD: Standard deviation,

Hb: Hemoglobin, ESR: Erythrocyte sedimentation rate, PCV: Packed cell volume, RBC: Red blood cell, MCV: Mean corpuscular volume, MCH: Mean corpuscular hemoglobin, MCHC: Mean corpuscular hemoglobin concentration, CBC: Complete blood count, $\mathrm{HbA}_{1} \mathrm{c}$ : Hemoglobin $\mathrm{A}_{1} \mathrm{c}$

normal and diabetic groups based on the empirically derived $\mathrm{HbA}_{1} \mathrm{c}$ (Table 3).

Table 4 presents the percentage changes of the biochemical and CBC measures among the normal and diabetic groups in the studied population. The increase or decreases of the various measures are common for the studied population irrespective of gender. However, the percentage level of changes was not uniform among the genders. It has been found that the biochemical measures of blood such as FBS, PPBS, $\mathrm{HbA}_{1} \mathrm{c}$, eAG, and estimated $\mathrm{HbA}_{1} \mathrm{c}$ using the derived empirical formula increased by $55 \%, 90 \%, 46 \%, 63 \%$, and $10 \%$, respectively, among the entire studied population. Similarly, the CBC measures $\mathrm{Hb}$, PCV, platelet count, RBC count, MCV, and MCH decreased by 8.5\%, 7.1\%, $1.3 \%, 4.2 \%, 3.1 \%$, and $5.8 \%$, respectively, among the diabetic subjects. The synthesis of the RBC is greatly affected by the onset of diabetes. Thereby resulting in decreased production of RBC and most likely leads to anemia. This results in the reduced measures of the various CBC measures associated with the RBC. Whereas, ESR and MCHC increased by $63 \%$ and $2 \%$, respectively, among the diabetic subjects. The performance characteristics of the empirically derived formula to estimate the $\mathrm{HbA}_{1} \mathrm{c}$ are presented in Table 5. It has been found that the sensitivity, specificity, positive predictive value (PPV), negative predictive value (NPV), and accuracy measures in the prediction of diabetes based on the estimated $\mathrm{HbA}_{1} \mathrm{c}$ are $91 \%, 49 \%, 67 \%, 83 \%$, and $71 \%$, respectively.

\section{DISCUSSION}

Diabetes is a disease, which is regarded as a global concern occurring due to elevated blood glucose levels. The condition arises mainly due to either inadequate secretion of insulin by the pancreas or improper consumption of glucose by the human body. Earlier studies have reported that the RBC in such hyperglycemic subjects experiences numerous variations, which could alter their flow properties mainly due to their deformation and aggregation [30].

The biochemical tests which are commonly used for routine assessment of diabetes are FBG, PPBS, $\mathrm{HbA}_{1} \mathrm{c}$, and eAG. However, $\mathrm{HbA}_{1} \mathrm{c}$ is the recommended diagnostic test for the clinical assessment of diabetes using a threshold $\left(\mathrm{HbA}_{1} \mathrm{c} \geq 6.5 \%\right.$ [7.7 $\left.\left.\mathrm{mmol} / \mathrm{L}\right]\right)$ recommended by the American Diabetes Association and the European Association for the study of diabetes $[13,31]$. Moreover, $\mathrm{HbA}_{\mathrm{c}}$ is also preferred than FBG because it requires overnight fasting, and whereas $\mathrm{HbA}_{1} \mathrm{c}$ test can also be carried out without any restrictions. This benefits for the subjects to

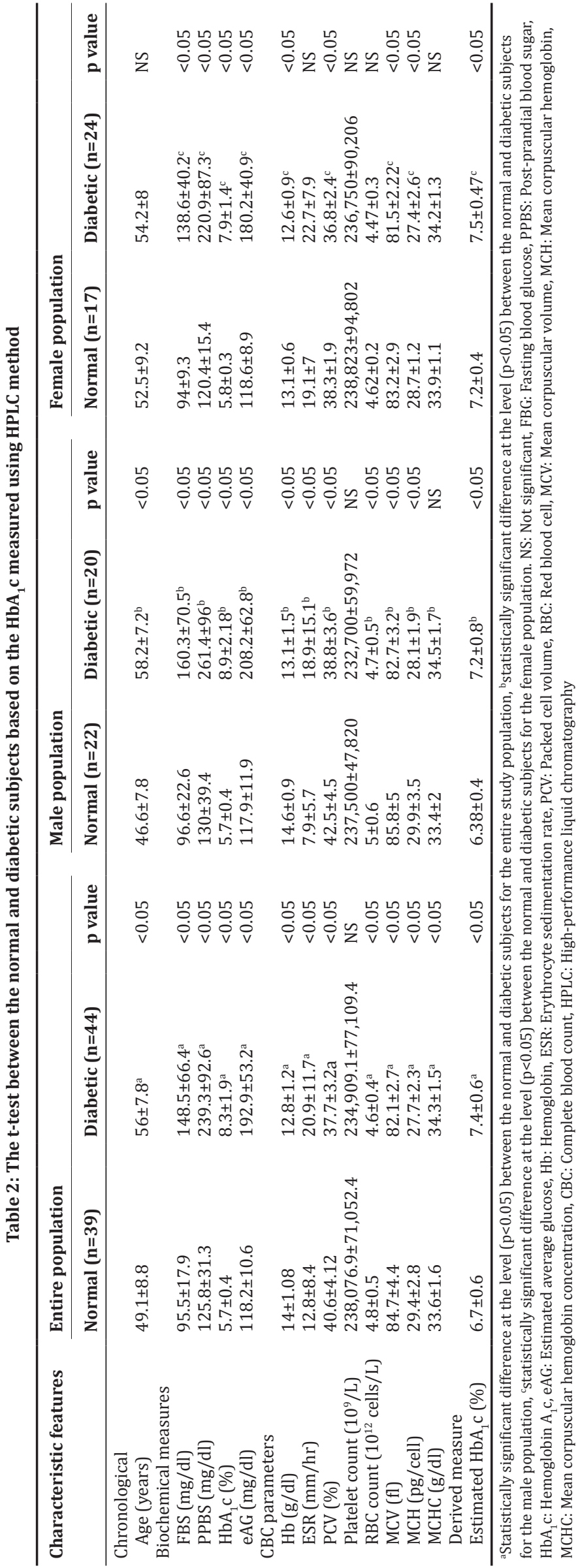




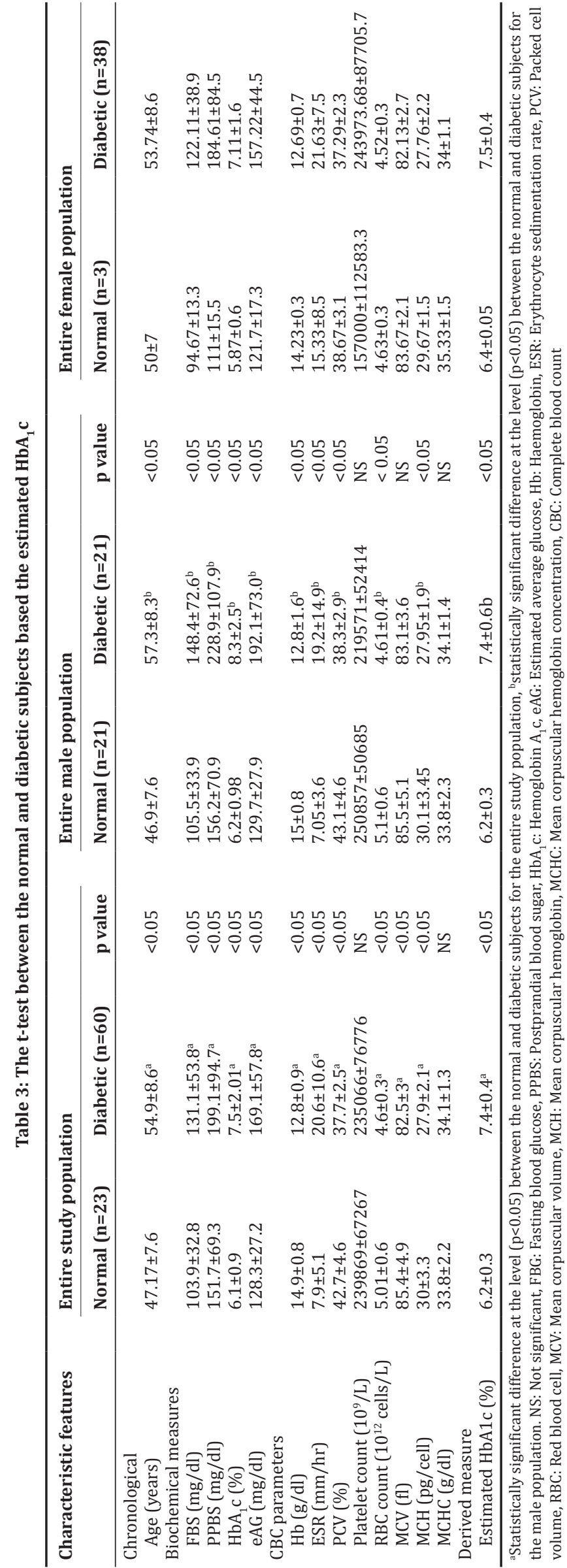

Table 4: Percentage variations of the biochemical measures and CBC parameters among the diabetic subjects on comparison with normal subjects

\begin{tabular}{|c|c|c|c|}
\hline Characteristic features & $\begin{array}{l}\text { Entire } \\
\text { population } \\
(n=83)\end{array}$ & $\begin{array}{l}\text { Male } \\
(n=42)\end{array}$ & $\begin{array}{l}\text { Female } \\
(n=41)\end{array}$ \\
\hline \multicolumn{4}{|l|}{ Biochemical measures } \\
\hline FBS (mg/dl) & $55 \uparrow$ & $66 \uparrow$ & $47 \uparrow$ \\
\hline PPBS (mg/dl) & $89.9 \uparrow$ & $101 \uparrow$ & $83 \uparrow$ \\
\hline $\mathrm{HbA}_{1} \mathrm{c}(\%)$ & $45.6 \uparrow$ & $56 \uparrow$ & $36 \uparrow$ \\
\hline eAG (mg/dl) & $62.7 \uparrow$ & $76.6 \uparrow$ & $52 \uparrow$ \\
\hline \multicolumn{4}{|l|}{ CBC parameters } \\
\hline $\mathrm{Hb}(\mathrm{g} / \mathrm{dl})$ & $8.5 \downarrow$ & $10.3 \downarrow$ & $3.8 \downarrow$ \\
\hline $\mathrm{ESR}(\mathrm{mm} / \mathrm{hr})$ & $63.9 \uparrow$ & $139.2 \uparrow$ & $18.8 \uparrow$ \\
\hline PCV (\%) & $7.1 \downarrow$ & 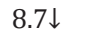 & $3.9 \downarrow$ \\
\hline Platelet count $\left(10^{9} / \mathrm{L}\right)$ & $1.3 \downarrow$ & $2 \downarrow$ & $0.9 \downarrow$ \\
\hline RBC count $\left(10^{12}\right.$ cells $\left./ \mathrm{L}\right)$ & $4.2 \downarrow$ & $6 \downarrow$ & $3.2 \downarrow$ \\
\hline $\mathrm{MCV}(\mathrm{fl})$ & $3.1 \downarrow$ & $3.6 \downarrow$ & $2 \downarrow$ \\
\hline MCH (pg/cell) & $5.8 \downarrow$ & $6 \downarrow$ & $4.5 \downarrow$ \\
\hline $\mathrm{MCHC}(\mathrm{g} / \mathrm{dl})$ & $2.1 \uparrow$ & $3.3 \uparrow$ & $0.9 \uparrow$ \\
\hline \multicolumn{4}{|l|}{ Derived measure } \\
\hline Estimated $\mathrm{HbA}_{1} \mathrm{c}(\%)$ & $10.4 \uparrow$ & $12.8 \uparrow$ & $4.2 \uparrow$ \\
\hline \multicolumn{4}{|c|}{$\begin{array}{l}\uparrow \text { - Percentage increase, } \downarrow \text { - Percentage decrease. FBG: Fasting blood glucose, } \\
\text { PPBS: Post-prandial blood sugar, } \mathrm{HbA}_{\mathrm{A}} \mathrm{c} \text { : Hemoglobin } \mathrm{A}_{\mathrm{c}} \mathrm{c} \text {, eAG: Estimated } \\
\text { average glucose, Hb: Hemoglobin, ESR: Erythrocyte sedimentation rate, } \\
\text { PCV: Packed cell volume, RBC: Red blood cell, MCV: Mean corpuscular volume, } \\
\text { MCH: Mean corpuscular hemoglobin, MCHC: Mean corpuscular hemoglobin } \\
\text { concentration, CBC: Complete blood count }\end{array}$} \\
\hline
\end{tabular}

undergo a $\mathrm{HbA}_{1} \mathrm{c}$ test as it avoids the necessity to sacrifice their working hours. The main drawback of the $\mathrm{HbA}_{1} \mathrm{c}$ test is that it is costlier due to the increased cost of the assay, reagents, and devices used for performing the test. Earlier studies have revealed that the diabetes influences in the reduced synthesis of RBC cells. CBC test is performed to analyze the composition of the various constituents in the blood. It has been found that diabetes can result in changes of RBC morphology [16-18]. This creates a requirement to explore ways to identify the extent of diabetes among individuals who have been recommended for CBC examinations for diagnosis of various diseases. In an earlier study by Khanam et al., it was found that the subjects with chronic renal failure with anemia possess lower levels of $\mathrm{Hb}, \mathrm{PCV}$, and $\mathrm{RBC}$ count than the normal subjects also the levels of the blood measures decreased greatly with the severity of the disease [32]. When a similar approach was adopted in this study to find the similarities and differences among the CBC measures among the normal and diabetic subjects. The results of this study revealed that the levels of $\mathrm{Hb}, \mathrm{PCV}$, platelet count, $\mathrm{RBC}$ count, $\mathrm{MCV}$, and $\mathrm{MCH}$ are high in the normal subjects than the diabetic subjects for the entire population, and also a statistically significant difference was observed between the two groups at the level $(\mathrm{p}<0.05)$, except for platelet count. Whereas, ESR and MCHC had lower levels in the normal groups than the diabetic groups with a statistically significant difference at the level $(\mathrm{p}<0.05)$. When similar approach was performed by applying it to only male and female subjects, a similar trend was observed for both the genders as observed for the entire population. Therefore, the results of the study reveal that $\mathrm{CBC}$ parameters demonstrate statistically significant differences exist between the normal and diabetic subjects. The results of our study concur with the similar study on Nigerian population, wherein PCV is lesser among diabetic subjects than the normal subjects [33]. Similar studies were also carried out on Nigerian population to test the effectiveness of malaria treatment using the CBC parameters as the extent of the infection influences in the CBC measures [25].

In the present study, it was found that there exists a significant correlation for $\mathrm{Hb}\left(\mathrm{r}=-0.35^{* *}, \mathrm{p}<0.001\right)$, ESR $\left(\mathrm{r}=0.35^{* *}, \mathrm{p}<0.001\right)$, PCV $\left(\mathrm{r}=-0.23^{*}, \mathrm{p}<0.05\right)$, and estimated $\mathrm{HbA}_{1} \mathrm{c}\left(\mathrm{r}=0.36^{* *}, \mathrm{p}<0.001\right)$ against $\mathrm{HbA}_{1} \mathrm{c}$. Similarly, statistically significant correlation was observed for $\mathrm{HbA}_{1} \mathrm{c}$ against the morphological features of RBC indicating that changes in RBC morphology are inevitable among diabetic cells [4]. 
Table 5: Performance characteristics of the estimated $\mathrm{HbA}_{1} \mathrm{c}$ in identifying subjects with diabetes

\begin{tabular}{llllll}
\hline Performance characteristics & Sensitivity (\%) & Specificity (\%) & PPV (\%) & NPV (\%) & Accuracy (\%) \\
\hline Estimated $\mathrm{HbA}_{1} \mathrm{c}$ & 91 & 49 & 67 & 83 & 71 \\
& (CI: 78.3-97.5) & (CI: 32.4-65.2) & (CI: 59.2-73.4) & (CI: 63.9-92.7) & \\
\hline
\end{tabular}

CI: Confidence interval ; PPV: Positive predictive value, NPV: Negative predictive value, $\mathrm{HbA}_{1} \mathrm{c}$ : Hemoglobin $\mathrm{A}_{1} \mathrm{c}$

The RBC of a diabetic cell undergoes variations in its shape and form due to changes in blood glucose levels. Therefore, the features that correspond to these variations of RBC could be used to diagnosis diabetes. We adopted a method to estimate $\mathrm{HbA}_{1 \mathrm{c}}$ using the $\mathrm{CBC}$ parameters, and the performance measures were found to be with sensitivity, specificity, PPV, NPV, and accuracy measures of 91\%, 49\%, $67 \%, 83 \%$, and $71 \%$, respectively, in diagnosing diabetes based on the empirically derived $\mathrm{HbA}_{1} \mathrm{c}$. The major limitations of the study are that it involves a relatively small group of the study population and its confinement to a single ethnic group, which needs to be validated over a larger sample size and different ethnicities.

\section{CONCLUSION}

We found that there exists a connection between the various $\mathrm{CBC}$ measures that corresponds to RBC features of a normal and diabetic cell. The empirical formula derived to estimate $\mathrm{HbA}_{1} \mathrm{c}$ using $\mathrm{CBC}$ parameters could be useful in the prediction of diabetes with an appreciable sensitivity and a limited specificity.

\section{ACKNOWLEDGMENTS}

The authors would like to express their deep sense of gratitude to the management of SRM Hospital and Research Centre for providing the required facilitative infrastructure.

\section{REFERENCES}

1. Andayani TM, Ibrahim MI, Asdie AH. The association of diabetes related factor and quality of life in Type 2 diabetes mellitus. Int J Pharm Pharm Sci 2010;2(1):139-45.

2. Ibrahim R. Diabetes mellitus Type II: Review of oral treatment options. Int J Pharm Pharm Sci 2010;2(1):21-30.

3. Roglic G, Unwin N, Bennett PH, Mathers C, Tuomilehto J, Nag S, et al. The burden of mortality attributable to diabetes: Realistic estimates for the year 2000. Diabetes Care 2005;28(9):2130-5

4. Palanisamy V, Mariamichael A. Diagnosis of diabetes mellitus by extraction of morphological features of red blood cells using an Artificial neural network. Exp Clin Endocrinol Diabetes 2016;124(9):548-56.

5. China Faces "Diabetes Epidemic", Research Suggests. BBC. March 25; 2010.

6. Gale J. India's Diabetes Epidemic Cuts Down Millions Who Escape Poverty. Bloomberg. November 7; 2010. Available from: http://www. fullertreacymoney.com. [Last retrieved on 2012 Jun 08]

7. Diabetes can be Controlled in 80 Percent of Cases in India. IANS. News. Available from: http://www.biharprabha.com. [Last retrieved on 2014 Feb 06].

8. Indian Heart Association Why South Asians Facts Web. 30 April; 2015. Available from: http://indianheartassociation.org/why-indians-whysouth-asians/overview/. [Last retrieved on ???].

9. Wild S, Roglic G, Green A, Sicree R, King H. Global prevalence of diabetes. Diabetes Care 2004;27(5):1047-53

10. Kleinfield NR. Modern Ways Open India's Doors to Diabetes. New York Times: New York Times; 2006. [Last retrieved on 2012 Jun 8].

11. Saladin KS. Anatomy and Physiology: The Unity of Form and Function. $7^{\text {th }}$ ed. New York: McGraw-Hill; 2007.

12. Vuong J, Qiu Y, La M, Clarke G, Swinkels DW, Cembrowski G. Reference intervals of complete blood count constituents are highly correlated to waist circumference: Should obese patients have their own "normal values?" Am J Hematol 2014;89(7):671-7.

13. Mohan V, Vijayachandrika V, Gokulakrishnan V, Anjana RM, Ganesan A, Weber MB, et al. A1c cut points to define various glucose intolerance groups in Asian Indians. Diabetes Care 2010;33(3):515-9.

14. Chinmay S, Manjula SD, Bekur R, Rao KR. Association of increased levels of glycated haemoglobin with variations in red blood cell parameters in diabetic mellitus. Int J Adv Res 2015;3(6):31-7.

15. De Keijzer MH, van der Meer W. Automated counting of nucleated red blood cells in blood samples of newborns. Clin Lab Haematol 2002;24(6):343-5

16. Babu N, Singh M. Influence of hyperglycemia on aggregation, deformability and shape parameters of erythrocytes. Clin Hemorheol Microcirc 2004;31(4):273-80.

17. Manjunatha M, Singh M. Digital analysis of induced erythrocyte shape changes in hypercholesterolemia under in vitro conditions. Curr Sci 2000;79(11):1589-91.

18. Kanakaraj P, Singh M. Influence of hypercholesterolemia on morphological and rheological characteristics of erythrocytes. Atherosclerosis 1989;76(2-3):209-17

19. Bessis M. Red cell shapes. An illustrated classification and its rationale. Heidelberg Springer; 1973.

20. Marchesi VT. The red cell membrane skeleton: Recent progress. Blood 1983;61(1):1-11.

21. Lowe GD. Clinical Blood Rheology. Vol. 1. Boca Raton: CRC Press; 1988

22. Chien S, Dormandy J, Ernst E, Matrai A. Clinical Hemorheology. Boston: M. Nijhoff; 1987.

23. Stoltz JF, Singh M, Riha P. Hemorheology in Practice. Amsterdam: IOS Press; 1999.

24. Alam J, Mallik SC, Mukti MN, Hoque M, Hasan M, Islam S, et al. A comparative analysis of biochemical and hematological parameters in diabetic and non-diabetic adults. Adv Med Sci Int J 2015;2(1):1-9.

25. Ifeanyichukwu MO, Esan AJ. Evaluation of haemoglobin concentration, packed cell volume and red cell indices in pre-and post-anti-malaria drug treatment in plasmodium falciparum malaria infected and control individuals. Glob Adv Res J Microbiol 2014;3(2):2-7.

26. Yuvraj V, Indumathi J, Singh M. Effects of cigarette smoking on morphology and aggregation of erythrocytes. Clin Hemorheol Microcirc 2012;51:169-75.

27. Trinder P. Determination of glucose in blood using glucose oxidase with an alternative oxygen acceptor. Ann Clin Biochem 1969;6:24-7.

28. Bry L, Chen PC, Sacks DB. Effects of haemoglobin variants and chemically modified derivatives on assays for glycohemoglobin. Clin Chem 2001;47(2):153-63.

29. Nathan DM, Kuenen J, Borg R, Zheng H, Schoenfeld D, Heine RJ. Translating the A1C assay into estimated average glucose values. Diabetes Care 2008;31(8):1473-8.

30. Singh $\mathrm{M}$, Shin S. Changes in erythrocyte aggregation and deformability in diabetes mellitus: A brief review. Indian J Exp Biol 2009;47(1):7-15.

31. American Diabetes Association. Standards of medical care in diabetes. Diabetes Care 2011;34(1):S11-61.

32. Khanam S, Begum N, Hoque AM. Relationship of hemoglobin, packed cell volume and total count of RBC with the severity of chronic renal failure. Chattagram Maa-O-Shishu Hosp Med Coll J 2013;12(2):31-4.

33. Sakpa CL, Idemudia JO. Relationship between glycated haemoglobin, fasting plasma glucose, packed cell volume and albumin creatinine ratio in diabetic patients in South-South Nigeria. Br J Med Med Res 2014;4(2):766-75. 